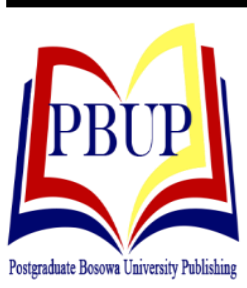

Postgraduate Bosowa University Publishing (PBUP)

Indonesian Journal of Business and Management e-ISSN: 2460-3767 p-ISSN: 2656-6885

https://postgraduate.universitasbosowa.ac.id/index.php/jbm

\title{
PENGARUH GAYA KEPEMIMPINAN TRANSFORMASIONAL, BUDAYA KERJA DAN KOMITMEN TERHADAP KEPUASAN KERJA ANGGOTA POLRI BIDPROPAM POLDA SULAWESI SELATAN
}

\author{
The Effect of Transformational Leadership, Work Culture and Commitment on \\ Work Satisfaction of Police Officers in Bidpropam Regional Police of South Sulawesi \\ Sri Wahyuni Jaspin ${ }^{1}$, Muhlis Ruslan ${ }^{2}$, Muhtar Sapiri $^{2}$ \\ ${ }^{1}$ Kepolisin Daerah Sulawesi Selatan \\ ${ }^{2}$ Program Studi Manajemen Program Pascasarjana Universitas Bosowa \\ Email: jaspinayu@gmail.com
}

Diterima: 11 Agustus 2020 /Disetujui: 05 Desember 2020

\begin{abstract}
ABSTRAK
Tujuan penelitian ini untuk mengetahui pengaruh gaya kepemimpinan transformasional, budaya kerja, komitmen terhadap kepuasan kerja anggota Polri. Penelitian ini adalah penelitian kuantitatif dengan metode analisis regresi linear berganda. Sampel diambil dengan teknik "cluster sampling" sebanyak lima puluh empat orang dari populasi sebanyak seratus sembilan belas orang. Dari hasil analisis membuktikan bahwa ada pengaruh signifikan antara gaya kepemimpinan transformasional terhadap kepuasan kerja artinya pimpinan Bidpropam Polda Sulsel telah menciptakan suasana kerja yang demokratis dan berlaku sebagai model dan motivator yang diharapkan anggotanya, demikian pula budaya kerja terhadap kepuasan kerja artinya anggota Polri Bidpropam Polda Sulsel sudah menanamkan nilai-nilai Tribrata dan Catur Prasetya sebagai pedoman dan falsafah hidup dalam setiap pelaksanaan tugas, dan komitmen terhadap kepuasan kerja artinya anggota Polri sudah menunjukkan kebanggaan dan kesetiaan kepada organisasi.
\end{abstract}

Kata Kunci: Gaya Kepemimpinan Transformasional, Komitmen, Budaya Kerja, Polda Sulawesi Selatan

\begin{abstract}
The research objective was to test the effect of transformational leadership, job culture, and commitment on work satisfaction of police officers. This study uses a quantitative approach with multiple regression analysis methods. The samples taken by "cluster sampling" technique were fifty four people out of one hundred and nineteen people. The analysis proves that there is a significant effect of transformational leadership on work satisfaction which means that police chief at the Work Unit in the Profession and Security Sector of the South Sulawesi Regional Police has created a democtratic work atmosphere and acted as a role model and motivator as expected by its members, and also effect of job culture on work satisfaction which means that members of the Police at the Work Unit in the Profession and Security Sector of the South Sulawesi Regional Police already have implemented tribrata and catur prasetya values as a guide and philosophy of life in every task implementation, and commitment on work satisfaction which means that members of the police have shown pride and loyalty to the organization.
\end{abstract}

Keywords: Transformational Leadership, Commitment, Work Culture,Polda, South Sulawesi 


\section{PENDAHULUAN}

Kepuasan kerja merupakan salah satu elemen yang cukup penting dalam organisasi. Hal ini disebabkan karena kepuasan kerja dapat mempengaruhi perilaku kerja seperti malas, rajin, produktif atau mempunyai hubungan dengan beberapa jenis perilaku yang sangat penting dalam organisasi. Faktor-faktor yang mempengaruhi kepuasan kerja antara lain, sistem gaji, kualitas dari supervisi, desentralisasi kekuasaan, tingkat kerja dan dorongan kerja, kondisi kerja yang menyenangkan, variabel kepribadian, status dan senioritas, pekerjaan yang sesuai dengan minat dan kepuasan hidup. Indikator-indikator tersebut merupakan bagian dari budaya kerja, komitmen dan gaya kepemimpinan transformasional. Terdapat beberapa penelitian terdahulu terkait dengan gaya kepemimpinan transformasional, budaya kerja dan komitmen terhadap kepuasan kerja. Penelitian yang dilakukan oleh Andrie Rondonuwu (2011), kesimpulan yang diperoleh adalah ada pengaruh kepemimpinan transformasional dan budaya organisasi secara bersama-sama terhadap kepuasan kerja. Kemudian penelitian yang dilakukan oleh Fahmi abdillah M (2015), kesimpulan yang diperoleh adalah ada pengaruh positif antara komitmen organisasi terhadap kepuasan kerja dan keterlibatan kerja melemahkan pengaruh positif komitmen organisasi terhadap kepuasan kerja. Kelengkap dan integral hasil penelitian bahwa pengaruh kepemimpinan yang baik akan memberikan dampak pada kinerja karyawan yang akan meningkat (Geoliling, 2021).

Peningkatan kompetensi merupakan ciri dari lingkungan yang senantiasa berubah. Hal ini sejalan dengan kebutuhan pemimpin transformasional (Abubakar, Herminawaty and Palisuri, Palipada, 2019). Satker Bidang Profesi dan Pengamanan Polda Sulawesi Selatan merupakan organisasi pemerintah yang bertugas membina dan menyelenggarakan fungsi pertanggungjawaban profesi dan pengamanan internal termasuk penegakan disiplin dan ketertiban di lingkungan Polri dan pelayanan pengaduan masyarakat tentang adanya penyimpangan tindakan anggota/PNS Polri. Hasil survey awal yang dilakukan pada Satker Bidang Profesi dan Pengamanan Polda Sulawesi Selatan terlihat bahwa gaya kepemimpinan pimpinan belum dapat meningkatkan secara signifikan kepuasan kerja. Salah satu, ukuran keberhasilan kepemimpinan dapat dilihat dari apakah organisasi mampu memberi motivasi kepada anggota agar supaya dapat menjalankan tugas dan tanggung jawabnya sesuai dengan harapan dan tujuan dari pada pelaksanaan kegiatan yang dimaksud.

Selain itu budaya kerja juga mampu mencerminkan ciri dari suatu instansi dengan instansi yang lainnya. Hal tersebut erat kaitannya dengan upaya instansi untuk membina anggotanya dengan berlandaskan nilai budaya yang ada agar nantinya mampu menciptakan anggota yang memiliki tanggung jawab yang besar dalam bekerja. Budaya kerja yang telah terbentuk menjadi bagian tak terpisahkan dari kepribadian para anggota dalam bekerja (Florentina \& Alim, 2020). Kenyataan di tempat kerja terdapat beberapa anggota satker yang tidak mematuhi aturan-aturan yang dibuat pimpinan instansi dimana aturan tersebut merupakan wujud penerapan budaya kerja yang berlaku di instansi. Melihat hal tersebut, penelitian ini bermaksud untuk mengetahui sampai sejauh manakah pengaruh gaya kepemimpinan transformasional, budaya kerja, dan komitmen terhadap kepuasan kerja anggota polri pada Satker Bidpropam Polda Sulsel.

\section{METODE PENELITIAN}

Penelitian ini termasuk dalam kategori penelitian asosiatif kausal dengan menggunakan pendekatan kuantitatif. Penelitian ini akan menjelaskan hubungan mempengaruhi dan dipengaruhi dari variabel-variabel yang akan diteliti, yaitu pengaruh variabel gaya kepemimpinan transformasional, variabel budaya kerja serta variabel komitmen terhadap variabel kepuasan kerja anggota polri pada Satker Bidpropam Polda Sulsel.

Populasi adalah keseluruhan objek penelitian (Arikunto, 2002). Populasi dalam penelitian ini merupakan populasi finit karena obyeknya adalah sebuah organisasi, yaitu Satker Bidpropam Polda Sulawesi Selatan dengan jumlah personil sebanyak 119 orang. Sampel adalah pengambilan sebagian dari seluruh populasi yang akan diteliti (Arikunto,2002). Teknik pengambilan sampel pada penelitian ini menggunakan teknik "cluster sampling". Teknik ini diambil karena pada Satker Bidpropam Polda Sulawesi Selatan terdiri dari 119 personil dibagi menjadi 6 bagian yaitu Subbid provos sebanyak 51 orang, Subbid paminal 34 orang, Subbid wabprof 14 orang, Subbag Yanduan 5 orang, Subbag rehabpers 4 orang dan Subbag renmin 11 orang. Jumlah sampel pada penelitian ini sebanyak 54 orang.

Metode pengumpulan data yang akan digunakan dalam penelitian ini adalah menggunakan kuesioner secara personal (personally administered questionnaires). Data dikumpulkan dengan menggunakan kuesioner (angket) tertutup, yaitu angket yang digunakan untuk mendapatkan data tentang gaya kepemimpinan transformasional, budaya kerja dan komitmen dalam usahanya untuk meningkatkan kepuasan kerja anggota polri.

Pertanyaan-pertanyaan dalam daftar pertanyaan dibuat dengan menggunakan skala likert dengan menggunakan lima variabel pilihan, setiap tingkatan diberi skor mulai dari tingkat yang rendah dengan skor 1 hingga tingkatan yang paling tinggi dengan skor 5. Sebelum kuisioner digunakan dalam pengumpulan data terlebih dahulu diuji validitas dan reabilitasnya. Teknik yang digunakan untuk menguji model dan hipotesis yang digunakan adalah analisis regresi linear berganda, uji parsial, uji signifikan simultan, dan uji koefisien determinasi.

\section{HASIL DAN PEMBAHASAN}

Pengujian instrumen dalam penelitian yang menggunakan kuisioner diperlukan untuk menentukan apakah alat pengukuran dapat digunakan atau tidak dalam proses pengumpulan data. Dalam pengujian ini dilakukan proses validitas dan reliabilitas jawaban kuisioner. Dengan dilakukan proses pengujian ini diharapkan hasil hipotesis dengan yang diharapkan. 
Pengujian validitas instrumen yaitu menghitung koefisien korelasi antara skor item dan skor totalnya dalam taraf signifikansi 95\% atau $\alpha=0.05$ (Santoso, 2015). Uji validitas dengan metode ini dilakukan menkorelasikan skor jawaban yang diperoleh masing-masing item dengan skor total dari keseluruhan item. Hasil korelasi harus siginifikan berdasarkan ukuran statistik. Koefisien korelasi yang tinggi menunjukkan kesesuaian antara fungsi item dengan fungsi ukur secara keseluruhan atau dengan kata lain instrumen tersebut valid. Validitas dilakukan dengan menggunakan koefisien korelasi product moment kriteria pengujian yang digunakan pada instrumen tersebut valid jika nilai $\mathrm{r}$ tabel pada tingkat signifikasi $5 \%$ dengan jumlah responden (n) 54 adalah 0,226.

1. Variabel Kepemimpinan Transformasional

Hasil uji instrumen kuesioner gaya kepemimpinan transformasional (X1) Untuk mengetahui tingkat validitas, maka dibandingkan nilai corrected item total correlation (nilai $r$ hitung) dengan nilai $r$ tabel.

Tabel 1. Hasil Uji Validitas Variabel Gaya Kepemimpinan Transformasional (X1)

\begin{tabular}{cccc}
\hline $\begin{array}{c}\text { Item } \\
\text { (Indikator) }\end{array}$ & r Hitung & r Tabel & Status \\
\hline X1.1 & 0.627 & 0.226 & Valid \\
X1.2 & 0.609 & 0.226 & Valid \\
X1.3 & 0.510 & 0.226 & Valid \\
X1.4 & 0.550 & 0.226 & Valid \\
X1.5 & 0.428 & 0.226 & Valid \\
X1.6 & 0.488 & 0.226 & Valid \\
X1.7 & 0.396 & 0.226 & Valid \\
X1.8 & 0.380 & 0.226 & Valid \\
\hline
\end{tabular}

Berdasarkan hasil uji validitas yang terlihat pada Tabel 1 maka diperoleh angka korelasi ( $r_{\text {hitung }}$ ) yang ternyata hasilnya lebih besar apabila dibandingkan dengan $\mathrm{r}$ tabel yang disyaratkan yaitu sebesar 0.226. Nilai Correction Item Total Correlation ( $\mathrm{r}_{\text {hitung }}$ ) variabel gaya kepemimpinan transformasional $\left(\mathrm{X}_{1}\right)$ berada diantara 0.380 - 0.627. Hasil ini menunjukkan bahwa nilai $r$ hitung > 0.226 ( $\mathrm{r}$ tabel), sehingga menunjukkan bahwa semua butir pernyataan pada kuisioner gaya kepemimpinan transformasioanl $\left(\mathrm{X}_{1}\right)$ adalah valid atau mampu mengungkapkan sesuatu yang akan diukur oleh kuisioner tersebut, sehingga dapat digunakan untuk analisis selanjutnya.

2. Variabel Budaya Kerja

Untuk mengetahui pengujian validitas pada variabel budaya kerja, disajikan dalam Tabel 2 berikut:

Tabel 2. Uji Validitas Variabel Budaya Kerja (X2)

\begin{tabular}{llll}
\hline $\begin{array}{c}\text { Item } \\
\text { (Indikator) }\end{array}$ & \multicolumn{1}{c}{ r Hitung } & r Tabel & Status \\
\hline X2.1 & 0.422 & 0.226 & Valid \\
X2.2 & 0.698 & 0.226 & Valid \\
X2.3 & 0.481 & 0.226 & Valid \\
X2.4 & 0.326 & 0.226 & Valid \\
X2.5 & 0.556 & 0.226 & Valid \\
X2.6 & 0.418 & 0.226 & Valid \\
X2.7 & 0.581 & 0.226 & Valid \\
X2.8 & 0.567 & 0.226 & Valid \\
\hline
\end{tabular}

Sumber: Data primer, diolah 2020
Berdasarkan hasil uji validitas yang terlihat pada tabel 2, maka diperoleh angka korelasi $\left(\mathrm{r}_{\text {hitung }}\right)$ yang ternyata hasilnya lebih besar apabila dibandingkan dengan $r$ tabel yang disyaratkan yaitu sebesar 0.226. Nilai Correction Item Total Correlation $\left(\mathrm{r}_{\text {hitung }}\right.$ ) variabel budaya kerja (X2) berada diantara 0.326 - 0.698. Hasil ini menunjukkan bahwa nilai $\mathrm{r}$ hitung $>0.226$ ( $\mathrm{r}$ tabel), sehingga menunjukkan bahwa semua butir pernyataan pada kuisioner budaya kerja (X2) adalah valid atau mampu mengungkapkan sesuatu yang akan diukur oleh kuisioner tersebut, sehingga dapat digunakan untuk analisis selanjutnya.

3. Variabel Komitmen

Untuk mengetahui pengujian validitas pada variabel komitmen, disajikan dalam Tabel 3 berikut:

Tabel 3. Hasil Uji Validitas Variabel Komitmen (X3)

\begin{tabular}{llll}
\hline $\begin{array}{c}\text { Item } \\
\text { (Indikator) }\end{array}$ & r Hitung & r Tabel & Status \\
\hline X3.1 & 0.535 & 0.226 & Valid \\
X3.2 & 0.565 & 0.226 & Valid \\
X3.3 & 0.424 & 0.226 & Valid \\
X3.4 & 0.539 & 0.226 & Valid \\
X3.5 & 0.534 & 0.226 & Valid \\
X3.6 & 0.279 & 0.226 & Valid \\
\hline
\end{tabular}

Sumber: Data Primer, Ddiolah 2020

Berdasarkan hasil uji validitas yang terlihat pada tabel 3, maka diperoleh angka korelasi ( $\mathrm{r}_{\text {hitung }}$ ) lebih besar dibandingkan dengan $\mathrm{r}$ tabel yang disyaratkan yaitu sebesar 0.226. Nilai Correction Item Total Correlation $\left(\mathrm{r}_{\text {hitung }}\right)$ variabel komitmen (X3) berada diantara 0.279 0.565 . Hasil ini menunjukkan bahwa nilai $r$ hitung $>0.226$ ( $\mathrm{r}$ tabel), sehingga menunjukkan bahwa semua butir pernyataan pada kuisioner komitmen (X3) adalah valid atau mampu mengungkapkan sesuatu yang akan diukur oleh kuisioner tersebut, sehingga dapat digunakan untuk analisis selanjutnya.

4. Variabel Kepuasan Kerja

Untuk mengetahui pengujian validitas pada variabel kepuasan kerja, disajikan dalam Tabel 4 berikut:

Tabel 4. Hasil Uji Validitas Variabel Komitmen (X3)

\begin{tabular}{cccc}
\hline Item (Indikator) & r Hitung & r Tabel & Status \\
\hline Y1 & 0.509 & 0.226 & Valid \\
Y2 & 0.344 & 0.226 & Valid \\
Y3 & 0.428 & 0.226 & Valid \\
Y4 & 0.358 & 0.226 & Valid \\
Y5 & 0.612 & 0.226 & Valid \\
Y6 & 0.763 & 0.226 & Valid \\
Y7 & 0.372 & 0.226 & Valid \\
Y8 & 0.589 & 0.226 & Valid \\
Y9 & 0.559 & 0.226 & Valid \\
Y10 & 0.515 & 0.226 & Valid
\end{tabular}

Berdasarkan hasil uji validitas yang terlihat pada Tabel 4 maka diperoleh angka korelasi ( $r_{\text {hitung }}$ ) yang ternyata hasilnya lebih besar apabila dibandingkan dengan $r$ tabel yang disyaratkan yaitu sebesar 0.226. Nilai Correction Item Total Correlation $\left(\mathrm{r}_{\text {hitung }}\right)$ variabel kepuasan kerja (Y) berada diantara $0.344-0.763$. Hasil ini menunjukkan bahwa nilai $\mathrm{r}$ hitung $>0.226$ ( $\mathrm{r}$ tabel), 
sehingga menunjukkan bahwa semua butir pernyataan pada kuisioner kepuasan kerja (Y) adalah valid atau mampu mengungkapkan sesuatu yang akan dukur oleh kuisioner tersebut, sehingga dapat digunakan untuk analisis selanjutnya.

Selanjutnya uji reliabilitas atau kehandalan instrumen merupakan pengujian tingkat konsistensi instrumen itu sendiri. Instrumen yang baik harus konsisten dengan butir yang diukur. Kehandalan instrumen dalam penelitian akan dianalisis dengan teknik alpha cronbach dengan menggunakan bantuan sarana komputer program SPSS. Nilai batas (cut of point) yang diterima untuk tingkat alpha cronbach adalah $\geq 0.60$, walaupun ini bukan merupakan standar absolut (Sekaran, 2011). Instrumen dianggap telah memiliki tingkat keandalan yang dapat diterima jika nilai koefisien reliabilitas yang terukur adalah $\geq 0.60$. Adapun hasil uji reliabilitas dari setiap variabel yang digunakan dalam penelitian ini dapat dilihat pada tabel berikut ini.

Tabel 5. Hasil Uji Reliabilitas Instrumen Penelitian

\begin{tabular}{lccc}
\hline \multicolumn{1}{c}{ Variabel } & $\begin{array}{c}\text { Cronbach's } \\
\text { Alpha }\end{array}$ & $\begin{array}{c}\text { Cut of } \\
\text { Point }\end{array}$ & Status \\
\hline Gaya kepemimpinan & 0.607 & 0.60 & Reliabel \\
Transformasional $\left(\mathrm{X}_{1}\right)$ & 0.605 & 0.60 & Reliabel \\
Budaya kerja $\left(\mathrm{X}_{2}\right)$ & 0.635 & 0.60 & Reliabel \\
Komitmen $\left(\mathrm{X}_{3}\right)$ & 0.670 & 0.60 & Reliabel \\
Kepuasan Kerja (Y) &
\end{tabular}

Sumber: Data Primer, Ddiolah 2020

Dari Tabel 5 pengujian reliabilitas dengan metode Cronbach's Alpha dapat diketahui bahwa nilai koefisien reliabilitas yang diukur adalah $\geq 0.60$. Berdasarkan hasil pengolahan data pada uji reliabilitas ini diperoleh nilai koefisien reliabilitas (Cronbach's Alpha) untuk variabel gaya kepemimpinan transformasional $\left(\mathrm{X}_{1}\right)$ sebesar 0.607; variabel budaya kerja $\left(\mathrm{X}_{2}\right)$ sebesar 0.605; variabel komitmen $\left(\mathrm{X}_{3}\right)$ sebesar 0.635 dan variabel kepuasan kerja (Y) sebesar 0.670. Karena seluruh nilai Cronbach's Alpha masing-masing variabel berada diatas ambang batas (cut of point) 0.60, maka dapat disimpulkan bahwa seluruh variabel memiliki tingkat keandalan yang dapat diterima.

Uji Asumsi Klasik

Uji asumsi klasik digunakan sebagai syarat dalam menggunakan model regresi agar hasil regresi yang diperoleh merupakan estimasi yang tepat.

a. Uji Multikolineritas

Dalam mendeteksi ada tidaknya gejala multikolinearitas antar variabel independen pada model persamaan maka digunakan variance inflation factor (VIF). Berdasarkan hasil yang ditunjukkan dalam output SPSS maka besarnya VIF dari masing-masing variabel independen dapat dilihat pada Tabel 6 sebagai berikut:

Tabel 6. Hasil Perhitungan VIF

\begin{tabular}{llc}
\hline \multirow{2}{*}{ Model } & \multicolumn{2}{c}{ Collinearity Statistics } \\
& Tolerance & VIF \\
\hline Gaya kepemimpinan transforma. (x1) & .843 & 1.186 \\
Budaya kerja (x2) & .580 & 1.724 \\
Komitmen (x3) & .598 & 1.672 \\
\hline
\end{tabular}

Sumber: Data Primer, Ddiolah 2020
Berdasarkan Tabel 6 diatas nilai tolerance semua variabel bebas (gaya kepemimpinan transformasional: 0.843 ; budaya kerja: 0.580 ; dan komitmen: 0,598) lebih besar dari nilai batas yang ditentukan yaitu sebesar 0,01 . Untuk nilai VIF terlihat bahwa semua variabel bebas memiliki nilai VIF yang kurang dari 10 (gaya kepemimpinan transformasional: 1.186; budaya kerja: 1.724; dan komitmen: 1.672). Maka dapat disimpulkan tidak terdapat gejala multikolinieritas antar variabel bebas dalam penelitian ini.

b. Uji Heteroskedastisitas

Heteroskedastisitas adalah suatu keadaan dimana varian dari kesalahan pengganggu tidak konstan untuk semua nilai variabel bebas, dimana uji ini bertujuan untuk menguji apakah dalam model regresi terjadi ketidaksamaan varian dari residual atau satu pengamatan lainnya. Untuk mendeteksinya dilihat dari titik-titik yang menyebar di atas dan di bawah angka 0 pada sumbu $\mathrm{Y}$ pada grafik Scatterplot.

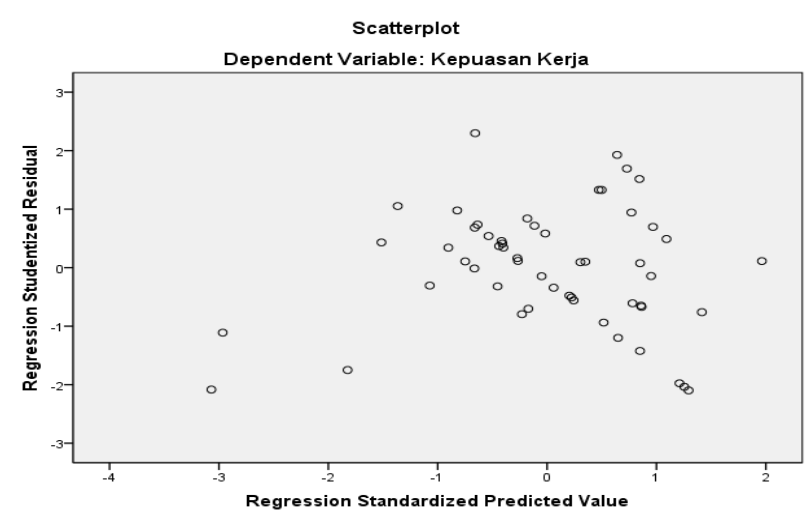

Gambar 1. Grafik Scatterplot Kepuasan Kerja

Dari Gambar 1 menunjukkan bahwa sebaran data residual tidak membentuk pola tertentu dan menyebar di bawah dan atas angka nol pada sumbu Y dengan demikian model terbebas dari gejala heteroskedastisitas.

c. Uji Normalitas

Uji normalitas digunakan untuk mengetahui apakah populasi data terdistribusi secara normal atau tidak, dengan demikian dapat dipakai dalam statistik parametrik. Dalam menguji normalitas data dalam penelitian ini digunakan uji Kolmogorov- Smirnov. Hasil pengujian normalitas dari Kolmogorov-Smirnov dapat dilihat secara ringkas pada tabel berikut:

Tabel 7. Hasil Uji Normalitas Data dengan KolmogorovSmirnov

\begin{tabular}{lcccc}
\hline \multicolumn{1}{c}{ Variabel } & $\begin{array}{c}\text { Kolmogo } \\
\text { rov- } \\
\text { Smirnov }\end{array}$ & $\begin{array}{c}\text { Asymp. } \\
\text { sig }\end{array}$ & Sig & Status \\
\hline $\begin{array}{l}\text { Kepemimpinan } \\
\text { Transformasional }\end{array}$ & 0.749 & 0.629 & $>0,05$ & Normal \\
$\begin{array}{l}\text { Budaya Kerja } \\
\text { Komitmen }\end{array}$ & 1.062 & 0.209 & $>0,05$ & Normal \\
\hline Sumber: Data Primer Ddiolah 2020 & & & &
\end{tabular}

Dari hasil perhitungan uji Kolmogorov-Smirnov, maka dapat diketahui bahwa apabila Signifikansi (Asymp.sig) > 0,05 maka data berdistribusi normal, dan 
sebaliknya apabila Signifikansi (Asymp.sig) < 0,05 maka data tidak berdistribusi normal. Pada output data tabel di atas dapat diketahui bahwa data Kepemimpinan Transformasional (X1) nilai Asymp.sig (2-tailed) sebesar 0,629 , data budaya kerja (X2) sebesar 0,209, dan data komitmen (X3) sebesar 0,284. Dengan demikian karena Signifikansi pada ketiga variabel lebih dari 0,05 maka dapat dinyatakan data berdistribusi normal.

\section{Uji Hipotesis}

Setelah pengujian validitas dan reliabilitas dilanjutkan uji asumsi klasik serta pengujian hipotesis yang dilakukan dengan menggunakan analisis regresi linier berganda, Uji Parsial Dengan T-Test, Uji Simultan Dengan F-Test (Anova ${ }^{b}$ ) dan Uji Koefisien Determinasi (R Square) yakni setelah data ordinal diubah ke data interval.

a. Analisa Regresi Linear Berganda

Untuk melihat pengaruh gaya kepemimpinan, budaya kerja dan komitmen terhadap kepuasan kerja, maka digunakan analisa regresi linear berganda. Berdasarkan hasil pengolahan data dengan bantuan program SPSS dapat dilihat rangkuman hasil empiris penelitian sebagai berikut:

Tabel 8. Output Hasil Regresi Berganda

\begin{tabular}{|c|c|c|c|}
\hline $\begin{array}{c}\text { Variabel } \\
\text { Konstanta }\end{array}$ & $\begin{array}{c}\text { Koefisien Regresi } \\
-0.063\end{array}$ & $\mathrm{~T}$ hitung & Sig \\
\hline $\mathrm{X} 1$ & 0,202 & 2,288 & 0,026 \\
\hline $\mathrm{X} 2$ & 0,501 & 4,291 & 0,000 \\
\hline X3 & 0,353 & 3,143 & 0,003 \\
\hline $\mathrm{R} 2$ & 0,667 & & \\
\hline F Hitung & 33,442 & & \\
\hline Sig (f) & 0.000 & & \\
\hline
\end{tabular}

Persamaan regresi berganda yang diperoleh dari hasil analisis yaitu: $\mathrm{Y}=-0.063+0.202 \mathrm{X}_{1}+0.501 \mathrm{X}_{2}+0.353$ $\mathrm{X}_{3}$. Persamaan regresi tersebut dapat diinterpretasikan sebagai berikut:

1. Konstantanta $-0,063$, nilai konstanta bernilai negatif artinya jika skor variabel gaya kepemimpinan transformasional, budaya kerja dan komitmen dianggap tidak ada atau sama dengan nol, maka skor kepuasan kerja anggota polri di Satker Bidpropam Polda Sulsel akan semakin berkurang atau tidak ada.

2. Koefisien X1 0,202, koefisien variabel gaya kepemimpinan transformasional bernilai positif artinya pengaruh gaya kepemimpinan transformasional terhadap kepuasan kerja anggota polri di Satker Bidpropam Polda Sulsel adalah bernilai positif dan cukup kuat. Jika gaya kepemimpinan transformasional membaik maka kepuasan kerja juga meningkat.

3. Koefisien X2 0,501, koefisien variabel budaya kerja bernilai positif artinya pengaruh budaya kerja terhadap kepuasan kerja anggota polri di Satker Bidpropam Polda Sulsel adalah bernilai positif dan cukup kuat. Jika budaya kerja membaik maka kepuasan kerja semakin tinggi.

4. Koefisien X3 0,353, koefisien variabel komitmen bernilai positif artinya pengaruh komitmen terhadap kepuasan kerja anggota polri di Satker Bidpropam
Polda Sulsel adalah bernilai positif dan cukup kuat. Jika komitmen membaik maka kepuasan kerja juga meningkat.

b. Uji Parsial Dengan T-Test

Berdasarkan Tabel 8 diatas menunjukkan bahwa:

1. Nilai $\mathrm{t}$ hitung untuk variabel gaya kepemimpinan transformasional terhadap kepuasan kerja diperoleh 2.288 dengan harga signifikansi 0.026 menunjukkan bahwa nilai $\mathrm{t}$ yang diperoleh tersebut signifikan karena harga signifikansi yang diperoleh kurang dari 0.05 .

2. Nilai t hitung untuk variabel budaya kerja terhadap kepuasan kerja diperoleh 4.291 dengan harga signifikansi 0.000 menunjukkan bahwa nilai $\mathrm{t}$ yang diperoleh tersebut signifikan karena harga signifikansi yang diperoleh kurang dari 0.05 .

3. Nilai $\mathrm{t}$ hitung untuk variabel komitmen terhadap kepuasan kerja diperoleh 3.143 dengan harga signifikansi 0.003 menunjukkan bahwa nilai t yang diperoleh tersebut signifikan karena harga signifikansi yang diperoleh kurang dari 0.05 .

c. Uji Simultan Dengan F-Test (Anova ${ }^{\mathrm{b}}$ )

Uji $F$ untuk menentukan apakah secara serentak/bersama-sama variabel independen mampu menjelaskan variabel dependen dengan baik atau apakah variabel independen secara bersama-sama mempunyai pengaruh yang signifikan terhadap variabel dependen. Berdasarkan Tabel 4.15 menunjukkan bahwa hasil pengujian hipotesis dengan perhitungan uji $F$ menggunakan program SPSS for Windows diperoleh $F$ hitung $=33,442$ yang lebih besar dari $\mathrm{F}$ tabel sebesar 2,56 dan dengan harga signifikansi sebesar 0.000. Karena harga signifikansi kurang dari 0.05 , menunjukkan bahwa nilai $\mathrm{F}$ hitung yang diperoleh tersebut signifikan.

d. Uji Koefisien Determinasi (R Square)

Derajat pengaruh antar gaya kepemimpinan, budaya kerja dan komitmen terhadap kepuasan kerja secara bersama-sama atau secara simultan dapat diketahui dari harga korelasi secara simultan dengan nilai $\mathrm{R}$ square sebesar 0.667. Besarnya pengaruh gaya kepemimpinan transformasional, budaya kerja dan komitmen dapat diketahui dari harga koefisien determinasi simultan $\left(\mathrm{R}^{2}\right)$ yang menunjukkan secara bersama-sama gaya kepemimpinan transformasional, budaya kerja dan komitmen memiliki pengaruh sebesar $66.7 \%$ terhadap kepuasan kerja.

Pengaruh Gaya Kepemimpinan Transformasional terhadap Kepuasan Kerja

Nilai t hitung untuk variabel gaya kepemimpinan transformasional terhadap kepuasan kerja diperoleh 2.288 dengan harga signifikansi 0.026 menunjukkan bahwa nilai $\mathrm{t}$ yang diperoleh tersebut signifikan karena harga signifikansi yang diperoleh kurang dari 0.05 . Karena nilai $t$ hitung 2.288 lebih besar dari t tabel 1.675 maka hipotesis nol (H0) ditolak dan hipotesis satu (H1) diterima, sehingga hal ini berarti bahwa variabel gaya kepemimpinan transformasional $\left(\mathrm{X}_{1}\right)$ memiliki pengaruh yang signifikan terhadap kepuasan kerja (Y). 
Hasil penelitian ini konsisten dengan hasil penelitian serupa sebelumnya yang dilakukan oleh Bambang Irianto (2002), yang menyimpulkan bahwa hubungan kepemimpinan dengan kepuasan kerja berkorelasi secara positif dan sangat signifikan. Penelitian lain yang mendukung adalah penelitian Dwidarsih (2001), dengan hasil penelitian menunjukkan adanya pengaruh positif dan signifikan kepemimpinan terhadap kepuasan kerja di BLK dengan kepuasan kerja instruktur, serta penelitian dari Rondonuwu (2011) dengan kesimpulan faktor kepemimpinan transformasional dan budaya organisasi secara bersama - sama telah memberikan kontribusi yang cukup signifikan terhadap kepuasan kerja anggota kepolisian di Polres Bogor Kota.

Menurut Nawawi (108-110), salah satu tolok ukur dalam mengevaluasi kepemimpinan dalam mengefektifkan organisasi, salah satunya adalah kepuasan kerja anggota organisasi/bawahan. Sejalan dengan pendapat tersebut, Bass dalam Yukl (2009: 305) menyatakan pemimpin dapat menerapkan gaya kepemimpinan transformasional ini dengan mengubah dan memotivasi para pengikut dengan cara:

a. Membuat mereka lebih menyadari pentingnya hasil tugas

b. Membujuk mereka untuk memetingkan kepentingan tim atau organisasi mereka dibandingkan dengan kepentingan pribadi.

c. Mengaktifkan kebutuhan mereka yang lebih tinggi.

Berdasarkan hasil ini sehingga hipotesis 1 yang menyatakan gaya kepemimpinan transformasional berpengaruh terhadap kepuasan kerja anggota Polri Satker Bidpropam Polda Sulsel, diterima.

Pengaruh Budaya Kerja terhadap Kepuasan Kerja

Nilai $\mathrm{t}$ hitung untuk variabel budaya kerja terhadap kepuasan kerja diperoleh 4.291 dengan harga signifikansi 0.000 menunjukkan bahwa nilai t yang diperoleh tersebut signifikan karena harga signifikansi yang diperoleh kurang dari 0.05 . Karena nilai t hitung 4.291 lebih besar dari t tabel 1.675 maka hipotesis nol (H0) ditolak dan hipotesis dua (H2) diterima, sehingga hal ini berarti bahwa variabel budaya kerja $\left(\mathrm{X}_{2}\right)$ memiliki pengaruh yang signifikan terhadap kepuasan kerja $(\mathrm{Y})$.

Hasil penelitian ini sejalan dengan hasil penelitian sebelumnya oleh Zakiul Amri Rizqina, (2017) yang menyatakan budaya kerja berpengaruh terhadap Kepuasan Kerja Pegawai Badan Pengusahaan Kawasan Sabang (BPKS). Budaya dalam suatu organisasi, baik organisasi pemerintah maupun swasta mencerminkan penampilan organisasi, bagaimana organisasi dilihat oleh orang yang berada di luarnya. Organisasi yang mempunyai budaya positif akan menunjukkan citra positif pula, demikian pula sebaliknya apabila budaya organisasi tidak berjalan dengan baik akan memberikan citra negatif dan ketidakpuasan kerja pada karyawannya (Wibowo, 2010). Apabila pada suatu organisasi dijalankan dengan sikap budaya organisasi positif dalam berorganisasi tentunya akan berdampak positif pada organisasi.

Berdasarkan hasil ini sehingga hipotesis 2 yang menyatakan budaya kerja berpengaruh terhadap kepuasan kerja anggota Polri Satker Bidpropam Polda Sulsel, diterima.

Pengaruh Komitmen terhadap Kepuasan Kerja

Nilai $\mathrm{t}$ hitung untuk variabel komitmen terhadap kepuasan kerja diperoleh 3.143 dengan harga signifikansi 0.003 menunjukkan bahwa nilai $\mathrm{t}$ yang diperoleh tersebut signifikan karena harga signifikansi yang diperoleh kurang dari 0.05. Karena nilai t hitung 3.143 lebih besar dari t tabel 1.675 maka hipotesis nol (H0) ditolak dan hipotesis tiga $(\mathrm{H} 3)$ diterima, sehingga hal ini berarti bahwa variabel komitmen $\left(\mathrm{X}_{3}\right)$ memiliki pengaruh yang signifikan terhadap kepuasan kerja (Y).

Hal ini sejalan dengan hasil penelitian Zakiul Amri Rizqina, berteman (2017) yang menyatakan variabel budaya kerja, kemampuan, komitmen kerja dengan variabel intervening kepuasan kerja memiliki pengaruh untuk meningkatkan variabel kinerja sepanjang variabel independent dan intervening dapat ditingkatkan oleh pengelola kantor BPKS Sabang, serta pernyataan dari George \& Jones (2002) yakni ada empat komponen yang mempengaruhi tingkat kepuasan kerja, yaitu kepribadian, nilai-nilai (values), situasi pekerjaan dan pengaruh sosial. Komitmen organisasi merupakan dimensi perilaku penting yang dapat digunakan untuk menilai kecenderungan pegawai, mengidentifikasi dan keterlibatan seseorang yang relatif kuat terhadap organisasi, dan mengetahui keinginan anggota organisasi untuk tetap mempertahankan keanggotaannya dalam organisasi.

Berdasarkan hasil ini sehingga hipotesis 3 yang menyatakan komitmen berpengaruh terhadap kepuasan kerja anggota Polri Satker Bidpropam Polda Sulsel, diterima.

Pengaruh Gaya Kepemimpinan Transformasional, Budaya Kerja, dan Komitmen terhadap Kepuasan Kerja

Uji F untuk menentukan apakah secara serentak/bersama-sama variabel independen mampu menjelaskan variabel dependen dengan baik atau apakah variabel independen secara bersama-sama mempunyai pengaruh yang signifikan terhadap variabel dependen. Pada tabel Anova dapat dilihat pengaruh variabel independen gaya kepemimpinan transformasional, budaya kerja dan komitmen terhadap variabel dependen kepuasan kerja anggota Polri Bidpropam Polda Sulsel secara simultan/bersama. Berdasarkan Tabel 8 (Output hasil analisis regresi berganda) menunjukkan bahwa hasil pengujian hipotesis dengan perhitungan uji $F$ menggunakan program SPSS for Windows diperoleh $\mathrm{F}$ hitung $=33,442$ yang lebih besar dari $\mathrm{F}$ tabel sebesar 2,56 dan dengan harga signifikansi sebesar 0.000. Karena harga signifikansi kurang dari 0.05 , menunjukkan bahwa nilai $\mathrm{F}$ hitung yang diperoleh tersebut signifikan. Dengan demikian menunjukkan bahwa secara bersama-sama terdapat pengaruh yang signifikan gaya kepemimpinan transformasional, budaya kerja dan komitmen terhadap kepuasan kerja anggota Polri Bidpropam Polda Sulsel.

Faktor kepemimpinan transformasional, budaya kerja dan komitmen secara bersama- sama telah memberikan kontribusi yang signifikan terhadap kepuasan kerja anggota Polri Bidpropam Polda Sulsel. Hasil penelitian ini 
yang menunjukkan bahwa kepemimpinan transformasional, budaya kerja dan komitmen berpengaruh positif dan signifikan dengan kepuasan kerja anggota Polri Bidpropam Polda Sulsel. Ketiga gaya tersebut dapat diterapkan bersamaan dalam suatu organisasi dengan alasan pada praktik gaya kepemimpinan transformasional akan mampu meningkatkan kepuasan kerja bagi bawahan yang memiliki kebutuhan yang lebih tinggi seperti kebutuhan harga diri dan aktualisasi diri. Hasil ini diperkuat oleh penelitian serupa yang mendukung adalah penelitian oleh Rokhman dan Harsono (2006) yakni terjadi korelasi secara positif dan sangat signifikan antara gaya kepemimpinan transformasional dan budaya organisasi terhadap kepuasan kerja.

Derajat pengaruh antar gaya kepemimpinan, budaya kerja dan komitmen terhadap kepuasan kerja secara bersama-sama atau secara simultan dapat diketahui dari harga korelasi secara simultan dengan nilai $\mathrm{R}$ square sebesar 0.667. Ini mengindikasikan bahwa secara bersamasama variabel gaya kepemimpinan transformasional, budaya kerja dan komitmen terhadap kepuasan kerja masuk dalam kategori kuat. Besarnya pengaruh gaya kepemimpinan transformasional, budaya kerja dan komitmen dapat diketahui dari harga koefisien determinasi simultan $\left(\mathrm{R}^{2}\right)$ yang menunjukkan secara bersama-sama gaya kepemimpinan transformasional, budaya kerja dan komitmen memiliki pengaruh sebesar $66.7 \%$ terhadap kepuasan kerja. Sedangkan selebihnya sebesar 33.3\% adalah pengaruh faktor lain yang tidak dimasukkan ke dalam model ini.

Pada persamaan regresi hasil penelitian ini menunjukan bila terjadi perbaikan atau peningkatan nilai satu pada gaya kepemimpinan transformasional maka akan meningkatkan kepuasan kerja sebesar 0,202. Bila terjadi perbaikan atau peningkatan nilai satu pada budaya kerja maka akan meningkatkan kepuasan kerja sebesar 0,501 dan bila terjadi perbaikan atau peningkatan nilai satu pada komitmen maka akan meningkatkan kepuasan kerja sebesar 0,353. Dari persamaan tersebut dapat dilakukan perbaikan kedepan untuk selalu menjaga dan meningkatkan kepuasan kerja anggota Polri Bidpropam Polda Sulsel.

Berdasarkan hasil ini sehingga hipotesis 4 yang menyatakan gaya kepemimpinan transformasional, budaya kerja, dan komitmen berpengaruh terhadap kepuasan kerja anggota Polri Satker Bidpropam Polda Sulsel, diterima.

\section{KESIMPULAN DAN SARAN}

Hasil penelitian dan pembahasan dapat disimpulkan bahwa gaya kepemimpinan transformasional, budaya kerja dan komitmen membawa perubahan positif terhadap kepuasan kerja anggota Polri Bidpropam Polda Sulsel. Hal ini menunjukkan bahwa pimpinan Bidpropam Polda Sulsel telah menciptakan suasana kerja yang demokratis dan berlaku sebagai model dan motivator yang diharapkan anggotanya. Anggota Polri Bidpropam Polda Sulsel sudah menanamkan nilai-nilai Tribrata dan Catur Prasetya sebagai pedoman dan falsafah hidup dalam setiap pelaksanaan tugas serta menunjukkan kebanggaan dan kesetiaan kepada organisasi. Gaya kepemimpinan transformasional, budaya kerja dan komitmen secara bersama-sama memberikan kontribusi signifikan terhadap kepuasan kerja anggota Polri Bidpropam Polda Sulsel. Ini menunjukkan bahwa untuk meningkatkan kepuasan kerja anggota maka gaya kepemimpinan transformasional, budaya kerja dan komitmen harus ditingkatkan secara bersama-sama.

Saran yang diberikan yaitu Bidpropam Polda Sulsel perlu meningkatkan faktor gaya kepemimpinan transformasional, budaya kerja dan komitmen yang menjadi faktor penting yang berpengaruh langsung terhadap kepuasan kerja anggota Polri. Untuk penelitian selanjutnya disarankan untuk mengukur indikator lain yang berpengaruh terhadap gaya kepemimpinan transformasional, budaya kerja dan komitmen serta faktor independen lainnya yang mempengaruhi kepuasan kerja anggota Polri.

\section{DAFTAR PUSTAKA}

Abdillah, Fahmi. 2015. Pengaruh komitmen organisasi terhadap kepuasan kerja yang dimoderasi keterlibatan kerja pada BRI Kantor Cabang Kusuma Bangsa. Vol.8 No.1(2015) Maulidyansah.

Abubakar, Herminawaty and Palisuri, Palipada. 2019. The Role of Human Resources and Information Technology on Implementation of Business Process Reengineering Strategy. Proceedings of the 2018 International Conference on Islamic Economics and Business (ICONIES 2018). Atlantis Press. PP. 46-49

Arikunto, S. 2002. Prosedur Penelitian, Suatu Pendekatan Praktek Edisi Revisi $V$. Jakarta: Rineka Cipta

Dwidarsih, Retno. (2001). Hubungan antara Kepemimpinan, IklimOrganisasi dan karakteristik Individu dengan KepuasanKerja. Tesis. Jakarta.Fakultas Ilmu Sosial dan Ilmu Politik. Program Pasca Sarjana Universitas Indonesia.

Florentina, T., \& Alim, S. (2020). Factors Analysis of IPIP-BFM-50 as Big Five Personality Measurement in Bugis-Makassar Culture. Ecosystem, 20, 156-167

George, J.M., and Gareth R.Jones. (2002). Organizational Behaviour. Prentice Hall, New Jersey.

Goeliling, A., Marjuni, S., \& Said, M. (2021). Kepemimpinan Tranformasional: Determinan Faktor Kinerja Karyawan Hotel Harper Perintis ByAston Di Kota Makassar. Indonesian Journal of Business and Management, 2(2), https://doi.org/10.35965/jbm.v2i2.42

Irianto, Bambang. (2002). Analisis Budaya Organisasi, Komunikasi dan Kepuasan Kerja Pegawai di Lingkungan Sekretariat Kabinet. Tesis.Jakarta. Fakultas Ilmu Administrasi dan Kebijakan Publik. Program Pascasarjana. Universitas Indonesia.

Nawawi, Hadari. 2003. Manajemen Sumber Daya Manusia. Yogyakarta: Gajah Mada University Press.

Rokhman, Wahibur dan Harsono (2002). Peningkatan Pengaruh Kepemimpinan Transformasional Terhadap Kepemimpinan Transaksional Pada Komitmen 
Organisasi Dan Kepuasan Bawahan. Empirika, Volume 11, Juni

Rondonuwu, andrie. 2011. Pengaruh kepemimpinan transformasional dan budaya organisasi terhadap kepuasan kerja anggota kepolisian di Polres Bogor Kota. Tesis Pascasarjana UI. Jakarta.

Santoso, S. (2015). SPSS20 Pengolahan Data Statistik di Era Informasi, Jakarta, PT. Alex Media Komputindo, Kelompok Gramedia

Wibowo, (2010). Budaya Organisasi; Sebuah Kebutuhan untuk Meningkatkan Kinerja Jangka Panjang. Jakarta : Rajawali Pers.

Yukl, Gary. 2009. Kepemimpinan Dalam Organisasi. Jakarta: Frenhallindo

Zakiul Amri R, Muh. Adam, Syafruddin Chan. 2017. Pengaruh Budaya Kerja, Kemampuan, Komitmen Kerja terhadap Kepuasan Kerja Pegawai serta dampaknya terhadap kinerja BPKS. Jurnal Magister 